\title{
APLIKASI PENJADWALAN MATA PELAJARAN DI SMAN 31 MENGGUNAKAN ALGORITMA GENETIKA BERBASIS WEB
}

\author{
Ivan \\ Fakultas Teknologi dan Desain, Program Studi Teknik Informatika \\ Universitas Bunda Mulia \\ Email: leveldownn@gmail.com \\ Stephanus Raphael \\ Fakultas Teknologi dan Desain, Program Studi Teknik Informatika \\ Universitas Bunda Mulia \\ Email: raphael@stevinweb.com \\ Halim Agung \\ Fakultas Teknologi dan Desain, Program Studi Teknik Informatika \\ Universitas Bunda Mulia \\ Email: hagung@bundamulia.ac.id
}

\begin{abstract}
ABSTRAK
Sekolah Menengah Atas Negeri 31 memiliki kelas sebanyak 29 kelas yang masing-masing memiliki 3 jurusan yaitu IPA, IPS dan Bahasa. Masing masing jurusan memiliki jumlah kelas yang cukup banyak. Sehingga pembuatan jadwal mata pelajaran oleh pihak sekolah memerlukan waktu yang cukup lama dan menggangu kelancaran proses belajar dan mengajar. aplikasi penjadwalan mata pelajaran menggunakan algoritma genetika merupakan solusi yang tepat untuk SMAN31. Algoritma Genetika adalah Proses seleksi alamiah yang melibatkan perubahan gen yang terjadi pada individu melalui proses perkembang-biakan yang menjadi proses dasar dan menjadi perhatian utama. Metode pengembangan sistem yang digunakan dalam penelitian ini adalah Metode Waterfall. Hasil dari penelitian ini adalah aplikasi penjadwalan SMAN 31 Jakarta yang dapat menyusun jadwal yang baik secara otomatis. Kesimpulan dari penelitian ini adalah algoritma genetika dapat diimplementasikan pada aplikasi penjadwalan dibuktikan dengan menguji 30 contoh jadwal yang tersusun oleh aplikasi tanpa ada yang bertabrakan satu sama lain.
\end{abstract}

Kata kunci: SMAN31, algoritma, penjadwalan, genetika, populasi.

\begin{abstract}
Public High School 31 has 29 classes, each of which has three majors: Science, Sociology and Language. Each department has a sufficient number of classes. So that making the schedule of subjects the school takes a long time and disrupt the smooth process of learning and teaching. application of subject scheduling using genetic algorithm is the right solution for SMAN31. Genetic Algorithm is a natural selection process that involves the gene changes that occur in individuals through a process of proliferation that becomes a basic process and a major concern. System development method used in this research is Waterfall Method. The result of this research is SMAN 31 Jakarta scheduling application which can arrange a good schedule automatically. The conclusion of this study is that genetic algorithms can be implemented in scheduling applications evidenced by testing 30 sample schedules composed by applications without one colliding with each other.
\end{abstract}

Keywords: SMAN31, algorithm, scheduling, genetics, population.

\section{PENDAHULUAN}

Penjadwalan mata pelajaran di sekolah merupakan hal yang sangat penting dalam berlangsungnya kegiatan belajar mengajar di sekolah, jadwal ini bertujuan untuk mendukung, memperlancar, dan meningkatkan kualitas pendidikan. Secara umum jadwal mata pelajaran berfungsi untuk aktivitas akademik dalam meningkatkan kualitas mengajar dan kedisiplinan baik guru maupun siswa.

Sampai saat ini penjadwalan pelajaran di beberapa sekolah masih dilakukan secara manual oleh bagian kurikulum, dengan sebelumnya dilakukan rapat pembagian tugas bersama guru mata pelajaran. Dari 
penentuan banyaknya kelas, banyaknya guru di sekolah, dan banyaknya jam mengajar untuk setiap guru masih dilakukan secara manual. Alokasi dan penentuan guru merupakan elemen yang penting dalam penyusunan jadwal mata pelajaran, namun juga menjadi permasalahan yang umum dalam proses penyusunan jadwal.

Penelitian ini menggunakan beberapa referensi penelitian yang dilakukan oleh peneliti sebelumnya. Penelitian terdahulu pertama yang menggunakan algoritma genetika [1] yang telah menghasilkan penjadwalan pesanan tanpa adanya pelanggaran pada penjadwalan. Penelitian terdahulu kedua [2] yang telah menghasilkan penjadwalan Mata kuliah tanpa adanya jadwal yang bertabrakan. Penelitian terdahulu ketiga [3] yang telah menghasilkan penjadwalan mata pelajaran tanpa adanya jadwal yang bertabrakan. Penelitian terdahulu keempat [4] yang dilakukan menghasilkan aplikasi yang dpat memprediksi waktu dan biaya pengerjaan proyek konstruksi yang dapat memberikan rekomendasi kepada kontraktor dalam pengerjaan proyek konstruksi. Penelitian terdahulu kelima membahas mengenai sistem rekomendasi wisata kuliner [5] dan disimpulkan bahwa dalam sistem rekomendasi wisata kuliner dengan menggunakan Algoritma Genetika, nilai fitness terbaik didapatkan dari metode crossover dengan satu titik potong dan mutasi dengan pergeseran gen. Kombinasi metode crossover dan mutasi ini menghasilkan nilai fitness ratarata sebesar 924 .

\section{METODOLOGI PENELITIAN}

\subsection{Algoritma Genetika}

Algoritma Genetika didasarkan pada proses genetik yang ada dalam makhluk hidup, yaitu perkembangan generasi dalam sebuah populasi yang alami, secara lambat laun mengikuti prinsip seleksi alam. Dengan meniru teori evolusi ini, Algoritma Genetika dapat digunakan untuk mencari solusi permasalahan-permasalahan dalam dunia nyata. Pada awal perkembangannya, metode Algoritma Genetika ini pertama kali diperkenalkan oleh John Holland dari Universitas Michigan pada tahun 1975 dalam bukunya yang berjudul "Adaption in Natural and Artificial Systems", dan pada akhirnya dipopulerkan oleh salah seorang muridnya, David Goldberg, yang mampu memecahkan masalah sulit yang melibatkan kontrol transmisi gas-pipa untuk disertasinya yang berjudul" Computer-aided gas pipeline operation using genetic algorithms and rule learning” [6].

Proses seleksi alamiah ini melibatkan perubahan gen yang terjadi pada individu melalui proses perkembang biakan. Dalam algoritma Genetika ini, proses perkembang-biakan ini menjadi proses dasar yang menjadi perhatian utama, dengan dasar berpikir "Bagaimana mendapatkan keturunan yang lebih baik". Algoritma Genetika ini ditemukan oleh John Holland dan dikembangkan oleh muridnya David Goldberg. Secara umum Algoritma Genetika menyelesaikan permasalahan dengan alur yang terdapat pada Gambar 1.

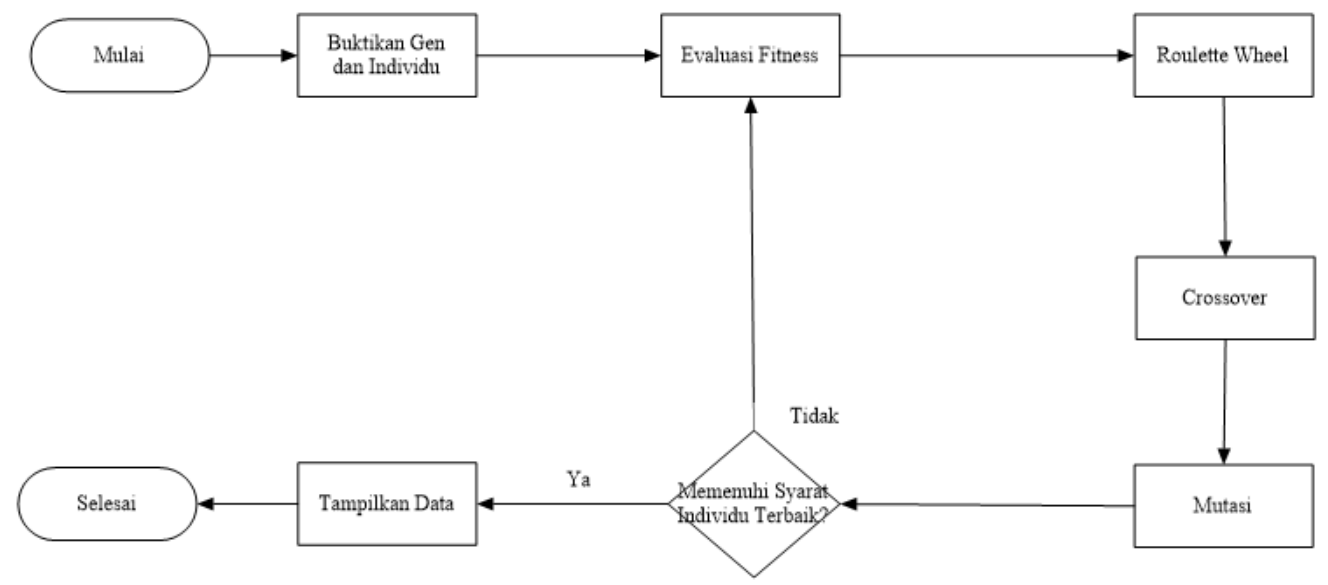

Gambar 1. Penyelesaian Algoritma Genetika Oleh David GoldBerg

\subsection{Evaluasi Nilai Fitness}

Untuk mengetahui baik tidaknya solusi yang ada pada suatu individu, setiap individu pada populasi harus memiliki nilai pembandingnya (fitness cost). Melalui nilai pembanding inilah akan didapatkan solusi terbaik dengan cara pengurutan nilai pembanding dari individu-individu dalam populasi.

Solusi terbaik ini akan dipertahankan, sementara solusi lain yang berubah untuk mendapatkan suatu solusi yang lain lagi, melalui tahap cross-over dan mutasi (mutation). Sebelum melakukan penempatan 
jadwal kelas dilakukan dua buah pengecekan terlebih dahulu, yaitu pencarian hari dan jam yang masih kosong dan pengecekan prioritas yaitu pada hari dan jam mana yang paling tinggi prioritasnya.

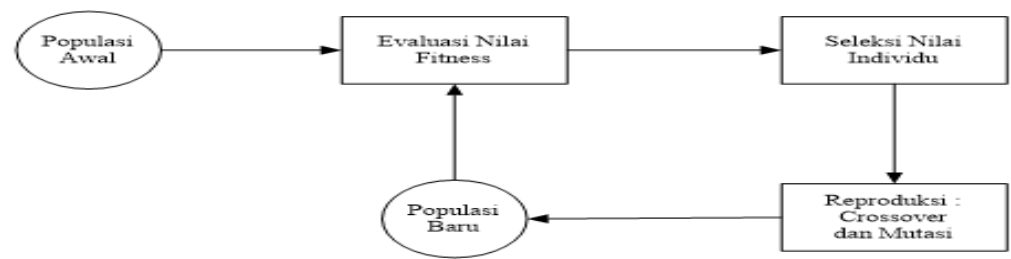

Gambar 2. Evaluasi Nilai Fitness Oleh David Goldberg

Tabel.1 Fitness cost

\begin{tabular}{|c|c|}
\hline Aturan & Fitness cost \\
\hline Jadwal bertabrakan & $\begin{array}{l}\text { Fitness cost - (jumlah mata kuliah bentrok } \\
\qquad 100)\end{array}$ \\
\hline Ruangan bertabrakan & Fitness cost $-($ jumlah responsi bentrok $* 100)$ \\
\hline Mapel olahraga di atas jam ke 2 & Fitness cost $-($ jumlah matakuliah semester $* 10)$ \\
\hline $\begin{array}{c}\text { Penumpukan jadwal yang sama dalam } \\
\text { sehari }\end{array}$ & $\begin{array}{l}\text { Fitness cost - (jumlah praktikum tidak sesuai } \\
\qquad 100)\end{array}$ \\
\hline
\end{tabular}

Proses evaluasi yang terdapat pada Gambar 2 melibatkan fungsi objektif yang merupakan formula untuk menentukan jumlah nilai yang salah dan dikalkulasikan dengan nilai fitness yang disajikan pada Tabel 1. Adapun evaluasi nilai fitness dilakukan dengan parameter sebagai berikut:

a. Tidak boleh terjadi tabrakan jadwal.

b. Tidak boleh terjadi penumpukan ruangan.

c. Mata pelajaran olahraga tidak boleh di atas jam ke 2 .

d. Tidak boleh terjadi penumpukan jadwal yang sama dalam satu hari.

Apabila terdapat aturan-aturan yang dilanggar maka nilai fitness cost akan dikurangi sehingga hasilnya akan menjadi lebih jelek

\section{HASIL DAN PEMBAHASAN}

\subsection{Perencanaan Sistem}

Setiap lembaga pendidikan sudah seharunya memiliki jadwal mata pelajaran agar kegiatan belajar mengajar dapat berjalan dengan lancar. saat ini pejadwalan di SMAN 31 masih dengan cara manual yaitu Tabel waktu (Time Table), perancangan jadwal dengan cara ini akan memakan waktu yang cukup lama Karena di sekolah SMAN 31 ini memiliki jumlah kelas sebanyak 29 kelas dengan 3 jurusan yang berbeda sehingga dapat mengurangi produktivitas belajar mengajar. Dengan harapan meningkatkan produktivitas belajar mengajar maka di buatlah aplikasi penjadwalan mata pelajaran di SMAN 31 dengan menggunakan Algoritma Genetika sebagai algoritma pencarian untuk menentukan jadwal yang tepat, sehingga dapat mendukung proses belajar mengajar di sekolah, untuk membuat aplikasi ini di butuhkan data mata pelajaran di SMAN31 yang disajikan pada Tabel 2 (Mata Pelajaran Jurusan IPA), Tabel 3 (Mata Pelajaran Jurusan IPS), dan Tabel 4 (Mata Pelajaran Jurusan Bahasa).

Tabel 2. Mata pelajaran jurusan IPA

\begin{tabular}{|c|c|}
\hline \multicolumn{2}{|c|}{ Kelas X,XI dan XII IPA } \\
\hline Matematika & Kewarganegaraan \\
\hline Bahasa Indonesia & Teknologi Informasi \\
\hline Bahasa Inggris & Seni Budaya \\
\hline Fisika & Olahraga \\
\hline Biologi & Elektronika \\
\hline Kimia & Sejarah Indonesia \\
\hline Pendidikan Agama & \\
\hline
\end{tabular}


Tabel 3. Mata pelajaran jurusan IPS

\begin{tabular}{|c|c|}
\hline \multicolumn{2}{|c|}{ Kelas X,XI dan XII IPS } \\
\hline Matematika & Pendidikan Agama \\
\hline Bahasa Indonesia & Kewarganegaraan \\
\hline Bahasa Inggris & Teknologi Informasi \\
\hline Ekonomi & Seni Budaya \\
\hline Geografi & Olahraga \\
\hline Sosiologi & Sejarah Indonesia \\
\hline Prakarya & Sejarah Dunia \\
\hline \multicolumn{2}{|c|}{ Tabel 4. Mata pelajaran jurusan bahasa } \\
\hline \multicolumn{2}{|c|}{ Kelas X,XI dan XII Bahasa } \\
\hline Matematika & Pendidikan Agama \\
\hline Bahasa Indonesia* & Kewarganegaraan \\
\hline Bahasa Inggris & Teknologi Informasi \\
\hline Bahasa Jerman & Seni Budaya \\
\hline Antropologi & Olahraga \\
\hline Sastra indonesia & Sastra Inggris \\
\hline Prakarya & Sejarah Indonesia \\
\hline
\end{tabular}

\subsection{Waterfall Model}

Pengembangan aplikasi ini menggunakan metode waterfall karena metode ini mewakili semua bagian penting dalam proses pengembangan aplikasi sistem informasi. Selain itu model ini memiliki fase yang berurut dalam merancang aplikasi Penjadwalan Mata Pelajaran di SMAN31. Waterfall model merupakan model System Development Life Cycle (SDLC) klasik yang bersifat sistematis. Model ini terdiri dari beberapa fase yang dikerjakan secara berurutan untuk membangun software. Penjelasan dari fase-fase waterfall model yang digunakan adalah :

a. Requirements Definition

Menganalisis dan menentukan menu apa saja yang dibutuhkan dalam aplikasi dengan melakukan analisis spesifikasi kebutuhan pada aplikasi.

b. System and Software Design

Membuat rencana yang akan dilakukan dalam aplikasi dengan merancang user interface dan desain untuk kebutuhan aplikasi yang akan dibuat dengan menggunakan arsitektur aplikasi, menggunakan metode $U M L$ serta flowchart sebagai desain alur kerja.

c. Implementation and Unit Testing

Menerjemahkan hasil desain ke dalam bahasa komputer berupa baris coding dalam bahasa pemograman $P H P$ dan kemudian dilakukan testing di setiap unit-unit program pada setiap fungsi.

d. Integration and System Testing

Program unit yang tidak memiliki error atau bugs akan digabungkan menjadi sebuah kesatuan program atau sistem. Setelah digabungkan maka akan diuji secara keseluruhan menggunakan blackbox testing.

e. Operation and Maintenance

Hasil dari uji testing yang telah bebas dari error atau bugs dapat dioperasikan. Apabila ada penambahan fitur atau perbaikan maka dapat dilakukan pengembangan atau perbaikan sistem.

\subsection{Flowchart}

Flowchart merupakan gambar atau bagan yang memperlihatkan urutan dan hubungan antar proses beserta instruksinya. Dengan adanya flowchart urutan proses kegiatan menjadi lebih jelas. Jika ada penambahan proses maka dapat dilakukan lebih mudah. Setelah flowchart selesai disusun, selanjutnya pemrogram (programmer) menerjemahkannya ke bentuk program dengan bahasa pemograman. 
a. Flowchart Menu Mata Pelajaran

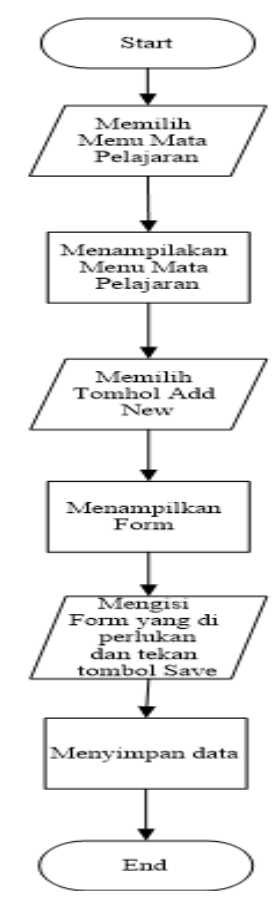

Gambar 3. Flowchart Mata Pelajaran

Gambar 3 adalah langkah-langkah yang di lakukan pada bagian menu mata pelajaran. Pertama user akan memilih тепи mata pelajaran dan sistem akan menampilkan tampilan mеnи mata pelajaran, kemudian user dapat memilih tombol add new untuk menambahkan mata pelajaran, kemudian sistem akan menampilkan Form untuk mengisi data mata pelajaran kemudian user menyimpan data.

b. Flowchart menu Guru

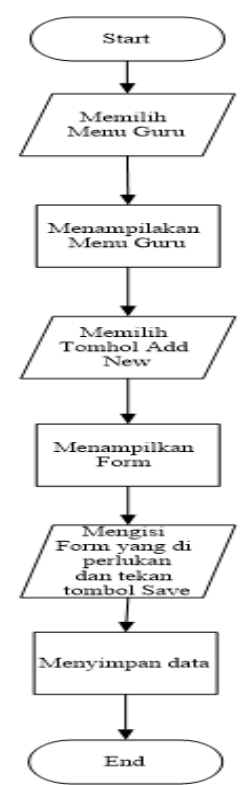

Gambar 4. Flowchart Guru

Gambar 4 adalah langkah-langkah yang di lakukan User saat sudah memilih menu Guru. Pertama user memilih menu guru kemudian sistem akan menampilkan tampilan menu Guru kemudian user dapat memilih tombol add new dan kemudian sistem akan menampilkan Form untuk mengisi data Guru yang di perlukan. 
c. Flowchart menu Kelas

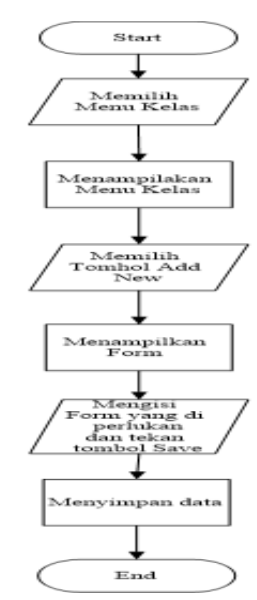

Gambar 5. Flowchart Kelas

Gambar 5 menunjukan langkah-langkah yang dapat di lakukan oleh User di dalam menu Kelas, Setelah User memilih menu kelas, maka sistem akan menampilkan menu kelas sehingga User dapat menambahkan data Kelas.

d. Flowchart Мепи Materi

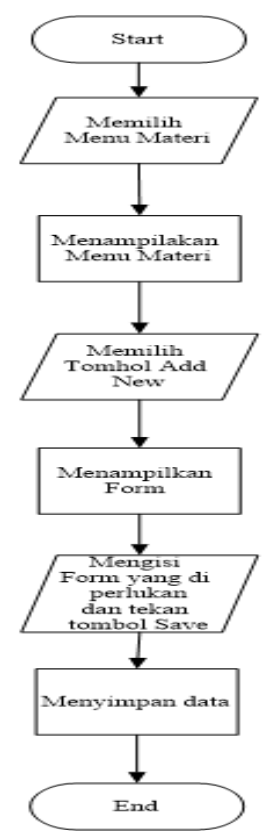

Gambar 6. Flowchart Materi

Gambar 6 adalah langkah-langkah User dalam menambahkan Materi-Materi Baru. Jika User memilih menu materi maka User dapat menambahkan Materi-Materi yang kurang kedalam aplikasi. 
e. Flowchart Menu Jurusan

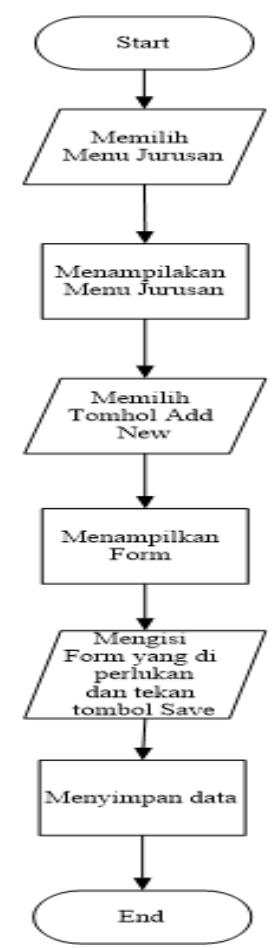

\section{Gambar 7. Flowchart Jurusan}

Gambar 7 adalah Langkah-langkah yang dapat di lakukan oleh User dalam menambahkan Jurusan. saat User Memilih menu jurusan, maka sistem akan menampilkan menu jurusan, kemudian User dapat menambahkan Jurusan yang lain.

f. Flowchart Menu Generate

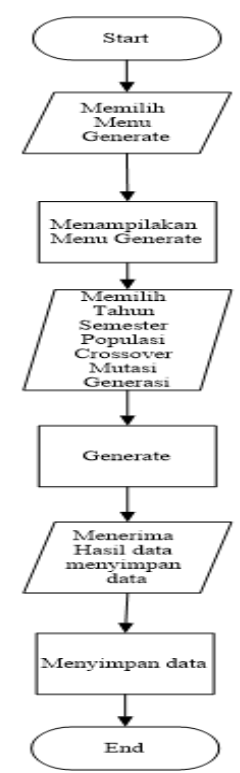

Gambar 8. Flowchart Generate

Gambar 8 adalah langkah-langkah dalam menampilkan data yang sudah di ada di menu-menu sebelumnya dan di lakukan generate sehingga User mendapatkan hasil Jadwal dari Algoritma Genetika. 


\subsection{Analisis Kebutuhan}

Dalam merancang sebuah aplikasi dibutuhkan banyak kebutuhan yang menunjang kesuksesan pembuatan aplikasi. Oleh karena itu diperlukannya analisis kebutuhan yang akan digunakan sebagai acuan terkait dengan kebutuhan yang diperlukan nantinya. Analisa kebutuhan bertujuan untuk memperoleh informasi mengenai kebutuhan input yang dibutuhkan untuk proses Penjadwalan Mata Pelajaran sehingga menjadi data untuk bisa mendapatkan hasil yang maksimal. Kebutuhan proses yaitu kebutuhan akan proses yang terjadi sebelum dilakukannya proses algoritma, dan kebutuhan output yang dibutuhkan dari sistem aplikasi yang ada. Kebutuhan masukan atau input yang dimaksud adalah kebutuhan input apa saja yang dibutuhkan pada saat proses pengerjaan algoritma Genetika dan sistem

\subsubsection{Analisis Kebutuhan Fungsional}

Sistem yang di rancang memiliki kebutuhan fungsional seperti pada umumnya yaitu :

a. Dapat memberikan sebuah hasil yaitu penjadwalan mata pelajaran di sekolah SMAN31.

b. Dapat memberikan kemudahan dalam pememeriksaan kurikulum / mata pelajaran di sekolah SMAN31.

\subsubsection{Analisis Kebutuhan Non Fungsional}

Dalam Perancangan Aplikasi ini, diperlukan spesifikasi sebagai berikut:

a. Sistem Operasi: Windows 7 SP1 atau lebih tinggi / Windows Server 2012 R2 (dengan update 2919355) atau lebih tinggi

b. Hardware: $1.8 \mathrm{GHz}$ or faster processor, Dual-core atau lebih baik / 2 GB of RAM atau lebih tinggi / Penyimpanan 1GB - 40GB / Video Card WXGA (1366 by 768) atau lebih baik

c. Lainnya: .NET framework 4.5 / Windows 10 Enterprise LTSB edition dan Windows $10 \mathrm{~S}$ hanya bisa Visual Studio 2017 / Internet Explorer 11 atau Edge / SQL Server 2014 atau SQL Server 2016

\subsection{Fungsi Fitness dan seleksi}

Individu-individu dalam populasi telah terbentuk, maka langkah selanjutnya adalah menghitung nilai fitness setiap individu. Penghitungan dilakukan dengan memberikan pinalti untuk setiap aturan yang digunakan dalam penjadwalan. Semakin wajib aturan dilaksanakan, maka akan semakin besar nilai pinalti yang diberikan. Aturan penghitungan fungsi fitness yang dapat dilihat pada persamaan 1 .

$f(g)=1 /\left(1+\sum P_{1} v_{1}(g)\right)$

Dimana $p_{1}$ adalah pinalti yang diberikan untuk aturan $i$, dan $v_{1}(\mathrm{~g})=1$ jika jadwal $g$ melanggar aturan $i$, bernilai 0 jika sebaliknya.

Tabel 5.Aturan dan seleksi fitness

\begin{tabular}{cc}
\hline Aturan & Nilai Pinalti \\
\hline Kesediaan waktu guru & 1 \\
Bentrok mata pelajaran wajib dan pilihan & 2 \\
Bentok waktu guru & 3 \\
Bentrok mata pelajaran satu semester & 3 \\
\hline
\end{tabular}

Apabila penghitungan fitness setiap indivudu telah dilakukan, maka langkah selanjutnya adalah seleksi induk. Seleksi yang digunakan adalah seleksi roda roulette yang terdapat pada Tabel 5. Pada seleksi roda roulette, semakin tinggi nilai fitness maka semakin besar kemungkinan untuk terpilih menjadi induk. 


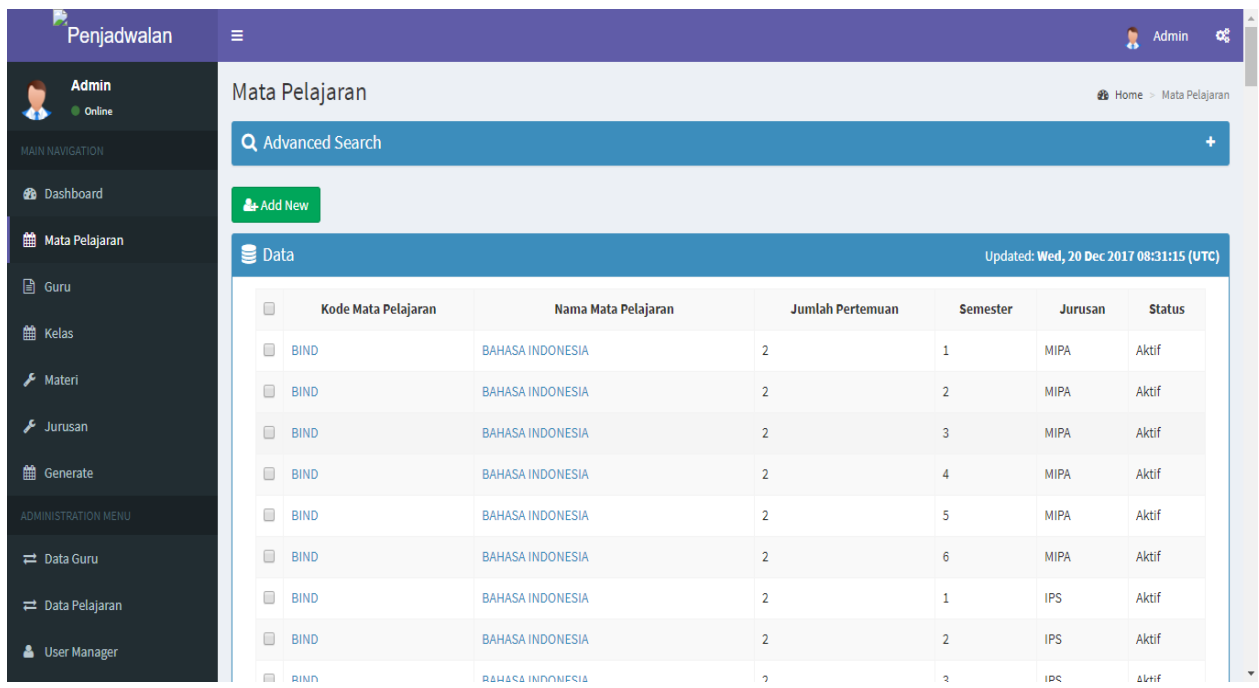

Gambar 10. Isi Data Mata Pelajaran Dari Aplikasi Penjadwalan

\begin{tabular}{|c|c|c|c|c|c|}
\hline Penjadwalan & \multicolumn{4}{|l|}{$\equiv$} & 8 Admin of \\
\hline 8. Admin & \multicolumn{4}{|l|}{ Guru } & a Home - Datater , Gun \\
\hline vanvengrion & \multicolumn{5}{|l|}{ Q Advanced Search } \\
\hline a Dastboard & \multicolumn{5}{|l|}{ \& Add New } \\
\hline 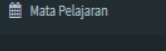 & \multicolumn{3}{|l|}{ @ Data } & \multicolumn{2}{|c|}{ Updated: Wed, 20 Dec 2017 08336:010 (UTC) } \\
\hline 圆 Guru & \multirow{2}{*}{$\begin{array}{l}\square \text { kode Curu } \\
\square \text { A1 }\end{array}$} & Nama Guru & Keterangan & Kepegawaian & status \\
\hline 整 Kelas & & Waluyo,S.Pd & & Honorer & Ahtif \\
\hline$f$ Materi & $\square A^{2}$ & Wahynningsih,s.Pd & & Honorer & Aktif \\
\hline \& Junsan & $\square$ A3 & Siti Nurhansanah,s.Pd & & Honorer & Ahtif \\
\hline 㭗 Generate & - $\mathrm{AA}$ & Surmadi,S.Pak,M.Si & & Honorer & Aktif \\
\hline 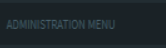 & $\square$ A5 & Henny Rahayy,S.Th & & Honorer & Ahtif \\
\hline$=$ Data Guru & 81 & Drs.sodikn,MM & & Honorer & Athif \\
\hline$=$ Datat Pelajaran & $\square \quad 82$ & Cipto Rojo,M.Mi & & Honorer & Ahtif \\
\hline I User Manager & в & Ima Anitas, S.Pd & & Honorer & Ahtif \\
\hline & $\square$ & Ner Rahnoriselah & & Hnonserer & shifif \\
\hline
\end{tabular}

Gambar 11. Tampilan Data Guru Dari Aplikasi Penjadwalan

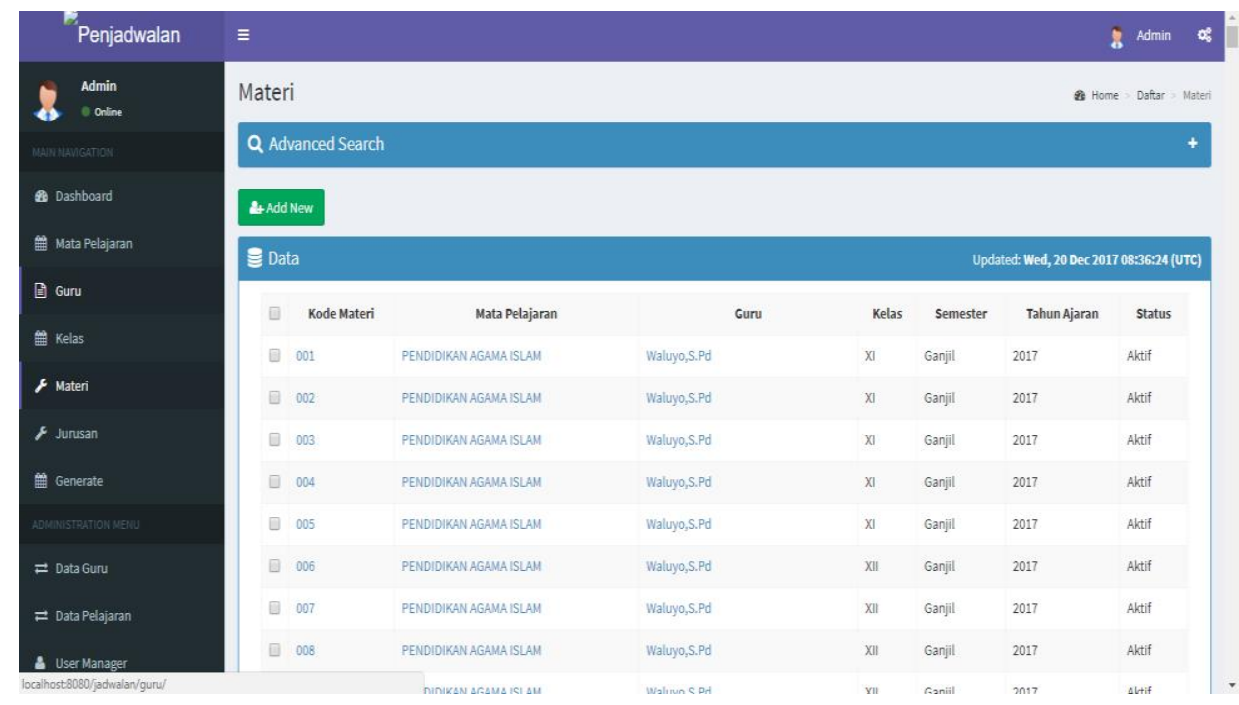

Gambar 12. Isi Data Materi Dari Aplikasi Penjadwalan 


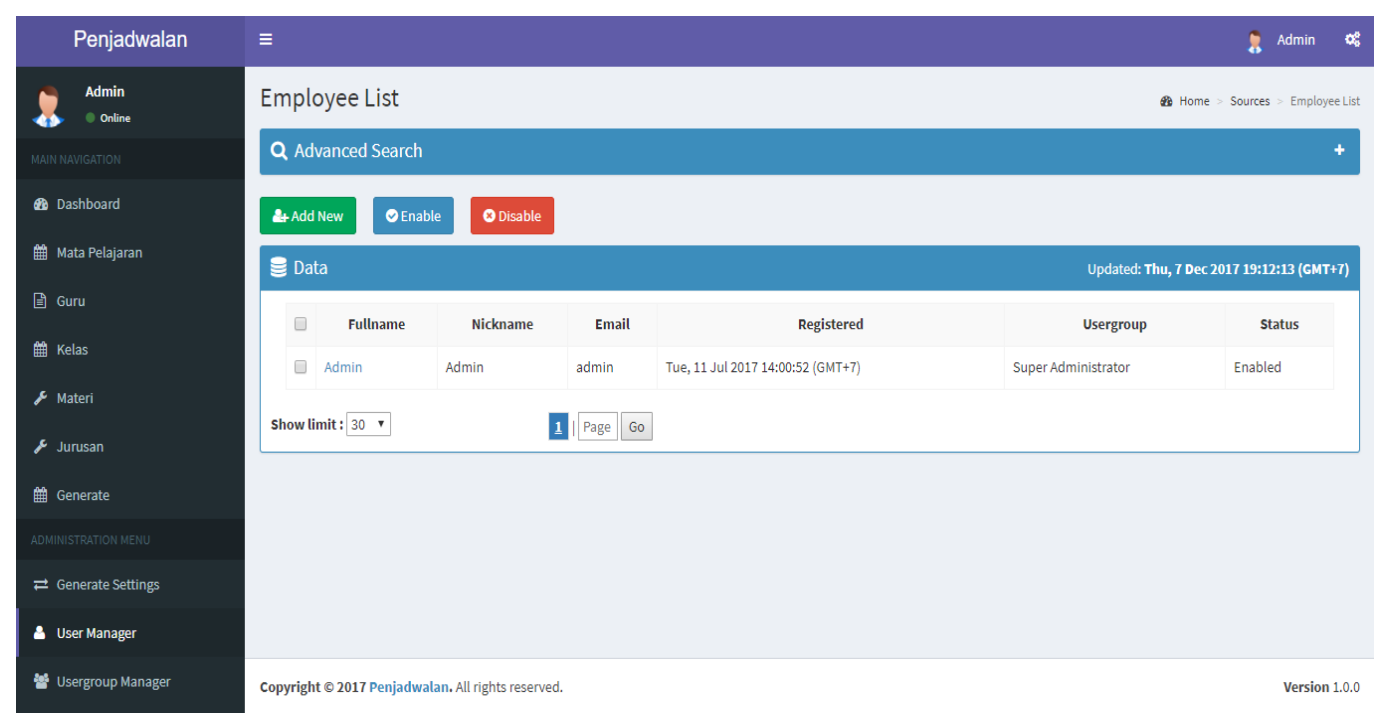

Gambar 13. Isi Data User Dari Aplikasi Penjadwalan.

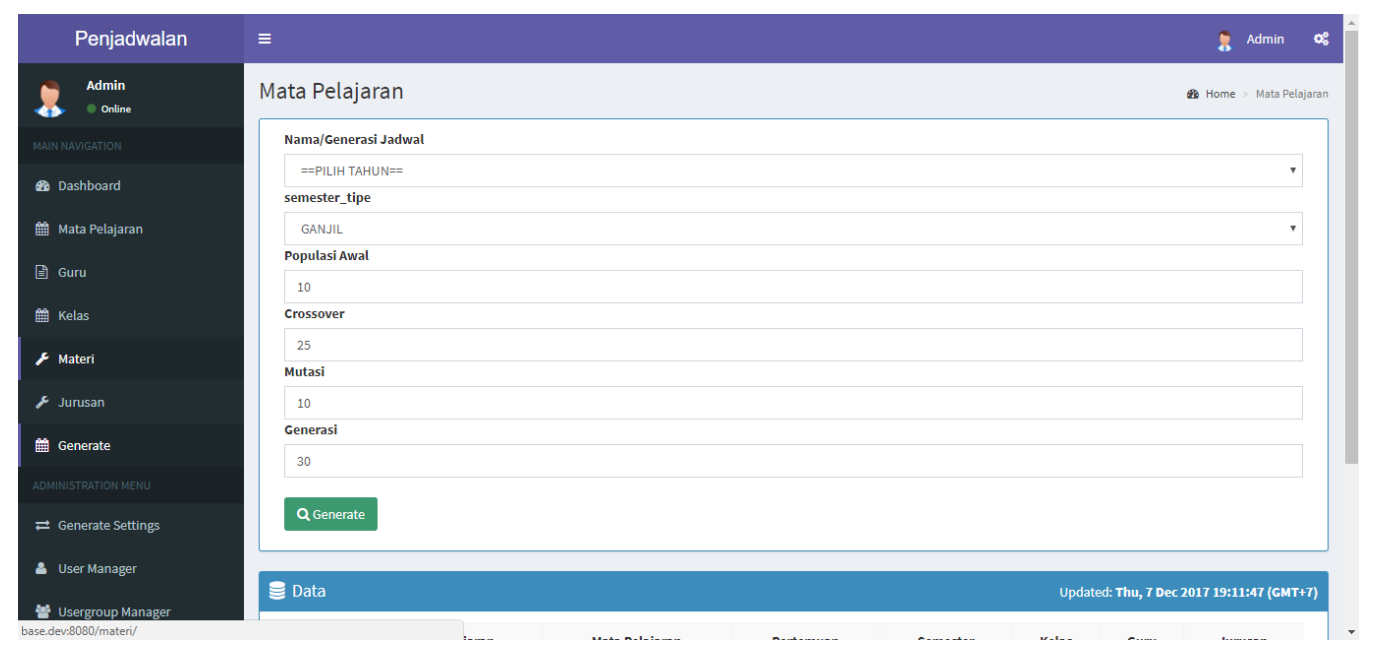

Gambar 14. Tampilan Menu Dari Generate

Berikut ini adalah cara perhitungan dari Generate yang telah di terapkan kedalam algoritma genetika:

\subsubsection{Pembentukan Chromosome}

Karena Pembentukan Chromosome yang di cari adalah jadwal maka variabel A1, A2, B1, B2, ... di jadikan sebagai gen-gen pembentuk kromosom. Batasan nilai variabel untuk hari adalah bilangan integer 1 sampai 5 dan batasan nilai variabel untuk jam adalah bilangan integer 1 sampai 10 .

\subsubsection{Inisialisasi}

Proses inisialisasi dilakukan dengan cara memberikan nilai awal gen-gen dengan nilai acak sesuai batasan yang telah ditentukan.Misalkan kita tentukan jumlah populasi adalah 6, maka:

Chromosome[1] $=[\mathrm{A} 1 ; \mathrm{A} 2 ; \mathrm{B} 1 ; \mathrm{B} 2 ; \ldots]=[[1][10] ;[4][4] ;[2][4] ;[1][8] ; \ldots]$

Chromosome $[2]=[\mathrm{A} 1 ; \mathrm{A} 2 ; \mathrm{B} 1 ; \mathrm{B} 2 ; \ldots]=[[4][9] ;[3][10] ;[5][2] ;[1][5] ; \ldots]$

Chromosome $[3]=[\mathrm{A} 1 ; \mathrm{A} 2 ; \mathrm{B} 1 ; \mathrm{B} 2 ; \ldots]=[[3][8] ;[5][9] ;[5][6] ;[2][5] ; \ldots]$

Chromosome $[4]=[\mathrm{A} 1 ; \mathrm{A} 2 ; \mathrm{B} 1 ; \mathrm{B} 2 ; \ldots]=[[5][7] ;[1][2] ;[2][7] ;[3][8] ; \ldots]$

Chromosome $[5]=[\mathrm{A} 1 ; \mathrm{A} 2 ; \mathrm{B} 1 ; \mathrm{B} 2 ; \ldots]=[[1][6] ;[2][6] ;[3][5] ;[5][5] ; \ldots]$

Chromosome $[6]=[\mathrm{A} 1 ; \mathrm{A} 2 ; \mathrm{B} 1 ; \mathrm{B} 2 ; \ldots]=[[3][2] ;[5][8] ;[5][2] ;[2][3] ; \ldots]$ 


\subsubsection{Evaluasi Chromosome}

Permasalahan yang ingin diselesaikan adalah nilai variabel A1, A2, B1, B2, ... yang tidak bertabrakan, maka fungsi_objektif yang dapat digunakan untuk mendapatkan solusi adalah fungsi_objektif $($ chromosome $)=\mid$ if $([\mathrm{i}][\mathrm{j}]==[\mathrm{i}+\mathrm{x}][\mathrm{j}+\mathrm{n}])$ fitness +1 Kita hitung fungsi_objektif dari chromosome yang telah dibangkitkan:

fungsi_objektif(chromosome[1]) $=0+0+1+1+0+1+1=4$

fungsi_objektif(chromosome[2]) $=0+1+0+0+0+1+0=2$

fungsi_objektif(chromosome[3]) $=1+0+0+1+1+0+1=4$

fungsi_objektif(chromosome[4]) $=1+1+0+1+0+1+1=5$

fungsi_objektif(chromosome[5]) $=1+0+1+0+0+1+0=3$

fungsi_objektif(chromosome[6]) $=0+1+1+0+0+0+1=3$

Rata-rata dari fungsi objektif adalah:

rata-rata $=(4+2+4+5+3+3) / 6=21 / 6=3,5$

\subsubsection{Seleksi Chromosome}

Proses seleksi dilakukan dengan cara membuat chromosome yang mempunyai fungsi_objektif kecil mempunyai kemungkinan terpilih yang besar atau mempunyai nilai probabilitas yang tinggi. Untuk itu dapat digunakan fungsi fitness $=(1 /(1+$ fungsi_objektif $))$, fungsi_objektif perlu ditambah 1 untuk menghindari kesalahan program yang diakibatkan pembagian oleh 0 .

$$
\begin{aligned}
& \text { fitness[1] }=1 /(\text { fungsi_objektif[1] }+1)=1 / 5=0.2 \\
& \text { fitness[3] }=1 /(\text { fungsi_objektif[3]+1) }=1 / 5=0.2 \\
& \text { fitness }[5]=1 /(\text { fungsi_objektif }[5]+1)=1 / 4=0.25 \\
& \text { total_fitness }=0.2+0.3333+0.2+0.1667+0.25+0.25=1.4
\end{aligned}
$$$$
\text { fitness[2] }=1 /(\text { fungsi_objektif[2]+1) }=1 / 3=0.3333
$$$$
\text { fitness[4] }=1 / \text { (fungsi_objektif[4]+1) }=1 / 6=0.1667
$$$$
\text { fitness[6] }=1 / \text { (fungsi_objektif[6]+1) }=1 / 4=0.25
$$

Rumus untuk mencari probabilitas: $\mathrm{P}[\mathrm{i}]=$ fitness[i] / total_fitness :

Dari probabilitas diatas dapat kita lihat kalau chromosome ke 2 yang mempunyai fitness paling besar maka chromosome tersebut mempunyai probabilitas untuk terpilih pada generasi selanjutnya lebih besar dari chromosome lainnya. Untuk proses seleksi kita gunakan roulete wheel, untuk itu kita harus mencari dahulu nilai kumulatif probabilitasnya:

$$
\begin{array}{ll}
\mathrm{C}[1] & =0.1428 \\
\mathrm{C}[2] & =0.1428+0.2381=0.3809 \\
\mathrm{C}[3] & =0.1428+0.2381+0.1428=0.5237 \\
\mathrm{C}[4] & =0.1428+0.2381+0.1428+0.1191=0.6428 \\
\mathrm{C}[5] & =0.1428+0.2381+0.1428+0.1191+0.1786=0.8214 \\
\mathrm{C}[6] & =0.1428+0.2381+0.1428+0.1191+0.1786+0.1786=1
\end{array}
$$

Setelah dihitung cumulative probabilitasnya maka proses seleksi menggunakan roulete-wheel dapat dilakukan. Prosesnya adalah dengan membangkitkan bilangan acak R dalam range 0-1.Jika R[k] < C [1] maka pilih chromosome 1 sebagai induk, selain itu pilih chromosome ke-k sebagai induk dengan syarat $\mathrm{C}[\mathrm{k}-1]<\mathrm{R}<\mathrm{C}[\mathrm{k}]$. Kita putar roulete wheel sebanyak jumlah populasi yaitu 6 kali (bangkitkan bilangan acak R) dan pada tiap putaran, kita pilih satu chromosome untuk populasi baru. Misal:

$\mathrm{R}[1]=0.201, \mathrm{R}[2]=0.284, \mathrm{R}[3]=0.009, \mathrm{R}[4]=0.822, \mathrm{R}[5]=0.398, \mathrm{R}[6]=0.501$,

Angka acak pertama R[1] adalah lebih besar dari C[1] dan lebih kecil daripada C[2] maka pilih chromosome[2] sebagai chromosome pada populasi baru, dari bilangan acak yang telah dibangkitkan diatas maka populasi chromosome baru hasil proses seleksi adalah:

chromosome[1] = chromosome[2]

chromosome[2] $=$ chromosome[2]

chromosome[3] $=$ chromosome[1] 


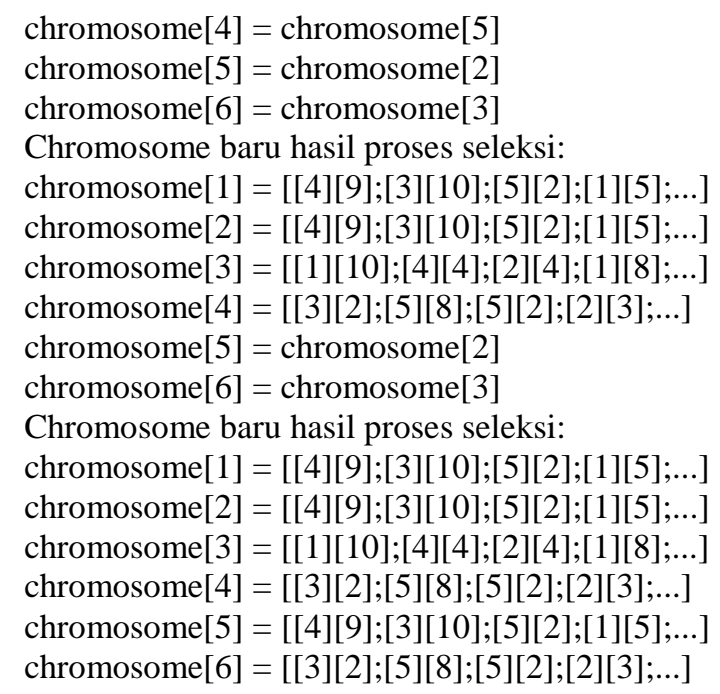

\subsubsection{Crossover}

Setelah proses seleksi maka proses selanjutnya adalah proses crossover. Metode yang digunakan salah satunya adalah one-cut point, yaitu memilih secara acak satu posisi dalam chromosome induk kemudian saling menukar gen. Chromosome yang dijadikan induk dipilih secara acak dan jumlah chromosome yang mengalami crossover dipengaruhi oleh parameter crossover_rate $(\rho \mathrm{c})$. Pseudocode untuk proses crossover adalah sebagai berikut:

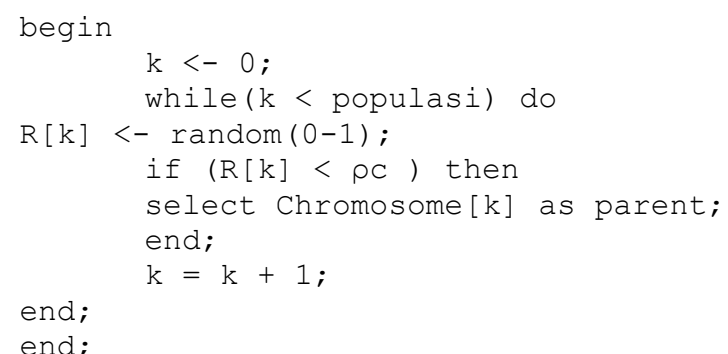

Misal kita tentukan crossover probability adalah sebesar 25\%, maka diharapkan dalam satu generasi ada 50\% Chromosome (3 chromosome) dari satu generasi mengalami proses crossover. Prosesnya adalah sebagai berikut:

Pertama kita bangkitkan bilangan acak R sebanyak jumlah populasi

$\mathrm{R}[1]=0.191, \mathrm{R}[2]=0.259, \mathrm{R}[3]=0.760, \mathrm{R}[4]=0.006, \mathrm{R}[5]=0.159, \mathrm{R}[6]=0.340$

Maka Chromosome ke k akan dipilih sebagai induk jika $\mathrm{R}[\mathrm{k}]<\rho \mathrm{c}$, dari bilangan acak $\mathrm{R}$ diatas maka yang dijadikan induk adalah chromosome[1], chromosome[4] dan chromosome[5]. Setelah melakukan pemilihan induk proses selanjutnya adalah menentukan posisi crossover. Ini dilakukan dengan cara membangkitkan bilangan acak dengan batasan 1 sampai (panjang chromosome-1), dalam kasus ini bilangan acak yang dibangkitkan adalah 1 - 3. Misalkan didapatkan posisi crossover adalah 1 maka chromosome induk akan dipotong mulai gen ke 1 kemudian potongan gen tersebut saling ditukarkan antar induk.

chromosome[1] $><$ chromosome[4], chromosome[4] $><$ chromosome[5], chromosome[5] $><$ chromosome[1]

Posisi cut-point crossover dipilih menggunakan bilangan acak 1-3 sebanyak jumlah crossover yang terjadi, misal

$\mathrm{C}[1]=1, \mathrm{C}[2]=1, \mathrm{C}[3]=2$

$\operatorname{offspring}[1]=$ chromosome[1] $\quad>\quad$ chromosome[4]= $[[4][9] ;[3][10] ;[5][2] ;[1][5] ; \ldots] \quad><$ $[[3][2] ;[5][8] ;[5][2] ;[2][3] ; \ldots]=[[4][9] ;[3][10] ;[5][2] ;[2][3] ; \ldots]$

offspring $[4]=$ Chromosome $[4]><$ Chromosome[5] $=[[3][2] ;[5][8] ;[5][2] ;[2][3] ; \ldots]><$ $[[4][9] ;[3][10] ;[5][2] ;[1][5] ; \ldots]=[[3][2] ;[5][8] ;[5][2] ;[1][5] ; \ldots]$

offspring[5] $=$ Chromosome[5] $><$ Chromosome[1] $=[[4][9] ;[3][10] ;[5][2] ;[1][5] ; \ldots]><$ [[4][9];[3][10];[5][2];[1][5];...]= [[4][9];[3][10];[5][2];[1][5];...]

Dengan demikian populasi Chromosome setelah mengalami proses crossover menjadi: 
chromosome[1] $=[[4][9] ;[3][10] ;[5][2] ;[2][3] ; \ldots]$

chromosome[2] $=[[4][9] ;[3][10] ;[5][2] ;[1][5] ; \ldots]$

chromosome[3] $=[[3][2] ;[5][8] ;[5][2] ;[1][5] ; \ldots]$

chromosome $[4]=[[4][9] ;[3][10] ;[5][2] ;[1][5] ; \ldots]$

chromosome[5] $=[[3][2] ;[5][8] ;[5][2] ;[1][5] ; \ldots]$

chromosome[6] $=[[4][9] ;[3][10] ;[5][2] ;[1][5] ; \ldots]$

\subsubsection{Mutasi}

Jumlah chromosome yang mengalami mutasi dalam satu populasi ditentukan oleh parameter mutation_rate. Proses mutasi dilakukan dengan cara mengganti satu gen yang terpilih secara acak dengan suatu nilai baru yang didapat secara acak. Prosesnya adalah sebagai berikut. Pertama kita hitung dahulu panjang total gen yang ada dalam satu populasi. Dalam kasus ini panjang total gen adalah total_gen = (jumlah gen dalam chromosome) $*$ jumlah populasi $=29 * 10 * 5 * 6=8700$, Untuk memilih posisi gen yang mengalami mutasi dilakukan dengan cara membangkitkan bilangan integer acak antara 1 sampai total_gen, yaitu 1 sampai 24. Jika bilangan acak yang kita bangkitkan lebih kecil daripada variabel mutation_rate $(\rho \mathrm{m})$ maka pilih posisi tersebut sebagai sub-chromosome yang mengalami mutasi. Misal $\mathrm{\rho m}$ kita tentukan 10\% maka diharapkan ada $10 \%$ dari total_gen yang mengalami populasi: jumlah mutasi $=0.1$ $* 8700=870$, Misalkan setelah kita bangkitkan bilangan acak terpilih posisi gen 12 dan 18 yang mengalami mutasi. Dengan demikian yang akan mengalami mutasi adalah chromosome ke-3 gen nomor 4 dan Chromosome ke-5 gen nomor 2. Maka nilai gen pada posisi tersebut kita ganti dengan bilangan acak 0-30. Misalkan bilangan acak yang terbangkitkan adalah 2 dan 5. Maka populasi chromosome setelah mengalami proses mutasi adalah:

chromosome[1] $=[[4][9] ;[4][10] ;[5][2] ;[2][3] ; \ldots]$

chromosome $[2]=[[4][9] ;[1][9] ;[5][2] ;[1][5] ; \ldots]$

chromosome $[3]=[[3][2] ;[5][8] ;[5][2] ;[4][7] ; \ldots]$

chromosome $[4]=[[4][9] ;[3][5] ;[5][2] ;[1][5] ; \ldots]$

chromosome[5] $=[[3][2] ;[2][8] ;[5][2] ;[5][5] ; \ldots]$

chromosome $[6]=[[4][9] ;[3][1] ;[5][2] ;[1][6] ; \ldots]$

Setelah proses mutasi maka kita telah menyelesaikan satu iterasi dalam algoritma genetika atau disebut dengan satu generasi. Maka fungsi_objective setelah satu generasi adalah:

fungsi_objektif(chromosome[1]) $=0+0+1+1+0+1+1=4$

fungsi_objektif(chromosome[2]) $=0+1+0+0+0+1+0=2$

fungsi_objektif(chromosome[3]) $=1+0+0+1+1+0+1=4$

fungsi_objektif(chromosome[4]) $=1+1+0+1+0+1+1=5$

fungsi_objektif(chromosome[5]) $=1+0+1+0+0+1+0=3$

fungsi_objektif(chromosome[6]) $=0+1+1+0+0+0+1=3$

Chromosome ini akan mengalami proses yang sama seperti generasi sebelumnya yaitu proses evaluasi, seleksi, crossover dan mutasi yang kemudian akan menghasilkan chromosome baru untuk generasi yang selanjutnya. Proses ini akan berulang sampai sejumlah generasi yang telah ditetapkan sebelumnya. Setelah 50 generasi didapatkan chromosome yang terbaik adalah Chromosome $=[[3][2] ;[2][8] ;[5][2] ;[5][5] ; \ldots]$ yang tidak memiliki bentrok pelajaran dan guru

Setelah mengimplementasikan Algoritma kedalam aplikasi pejadwalan maka di uji aplikasi tersebut sebanyak 30 kali, di bawah ini adalah salah satu contoh hasil dari aplikasi penjadwalan.
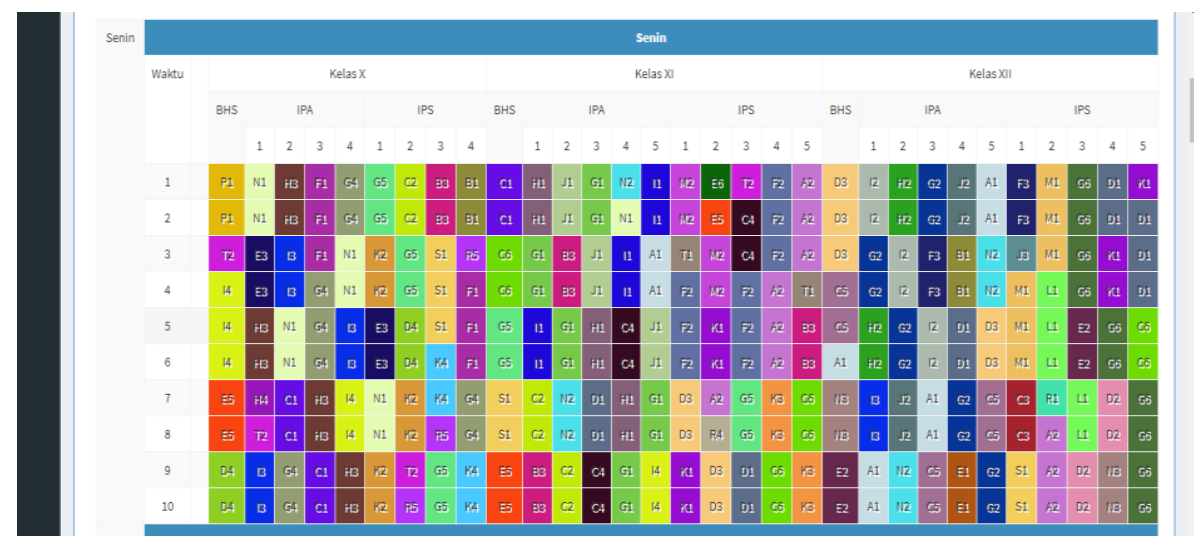

Gambar 16. Hasil Pengujian Jadwal A (Hari Senin) 


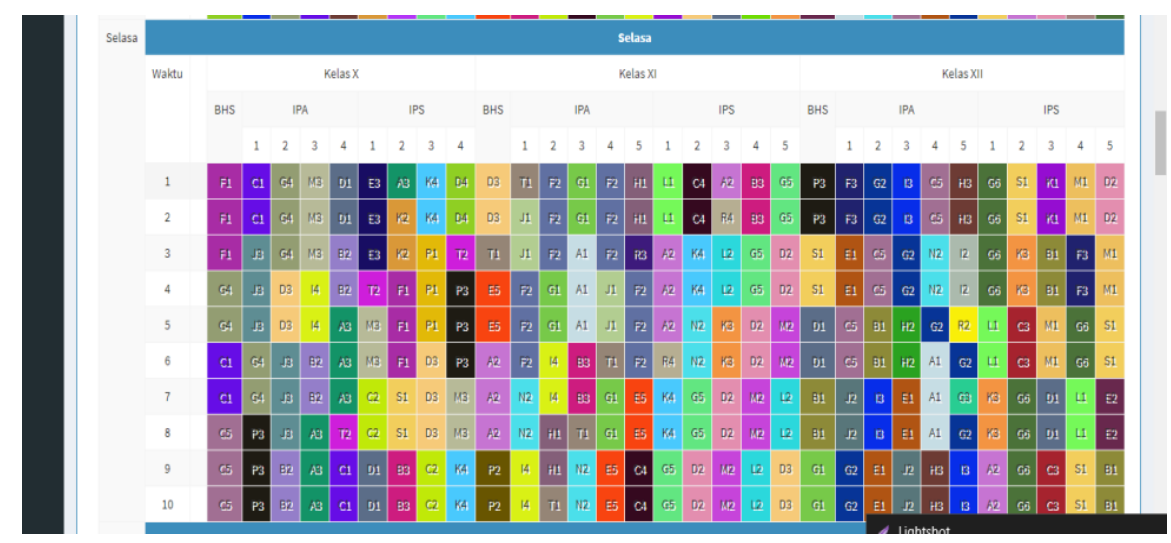

Gambar 17. Hasil Pengujian Jadwal B (Hari Selasa)

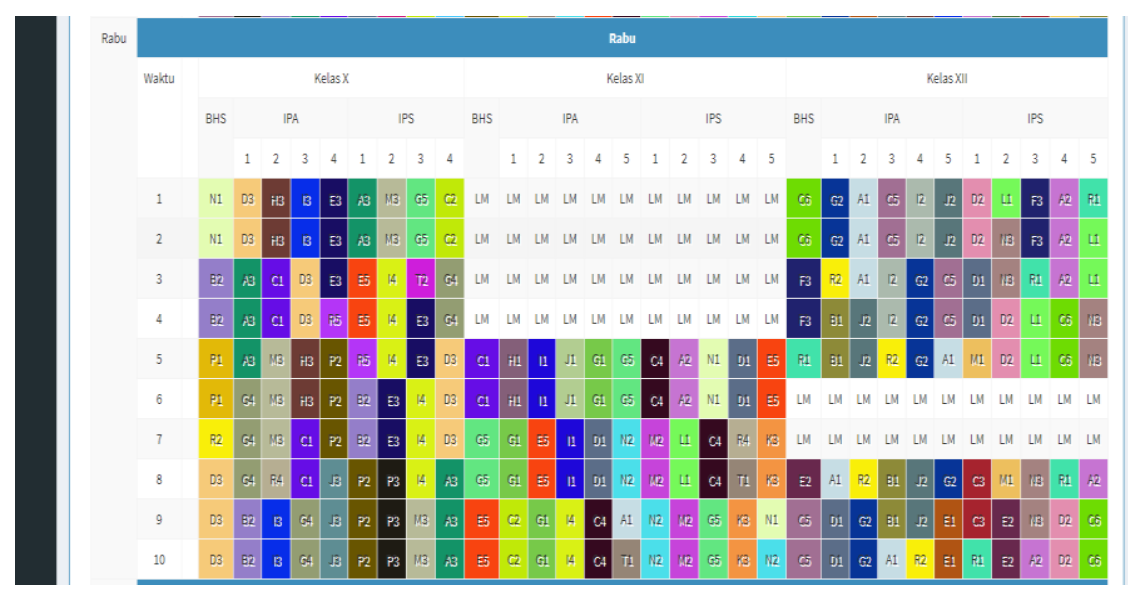

Gambar 18. Hasil Pengujian Jadwal C (Hari Rabu)

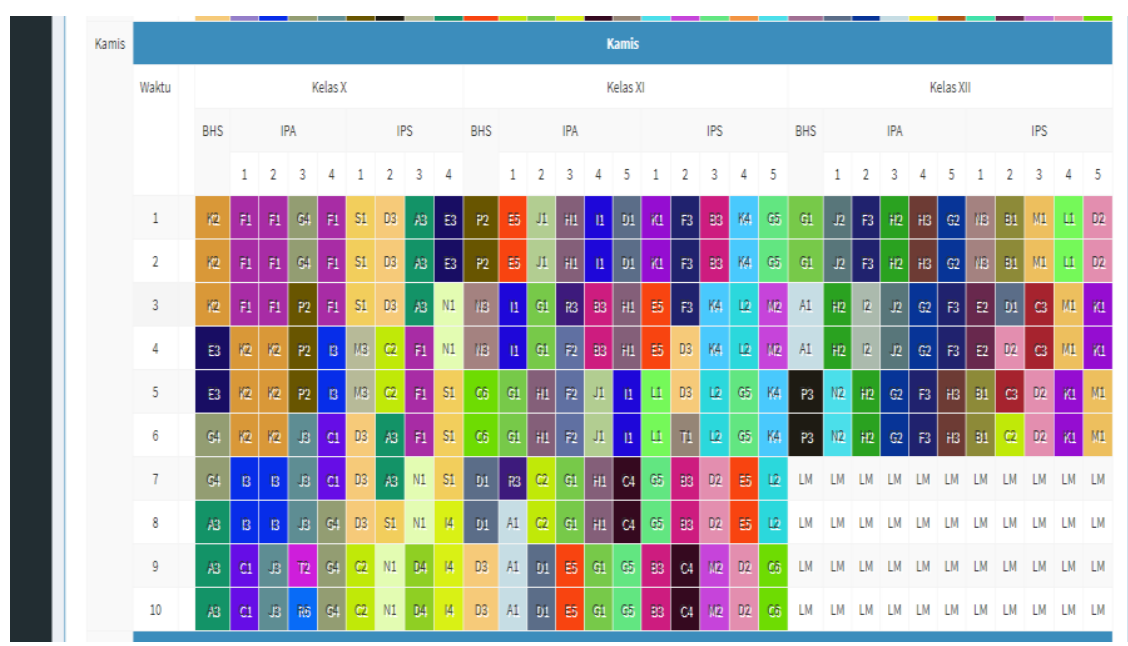

Gambar 19. Hasil Pengujian Jadwal D (Hari Kamis) 


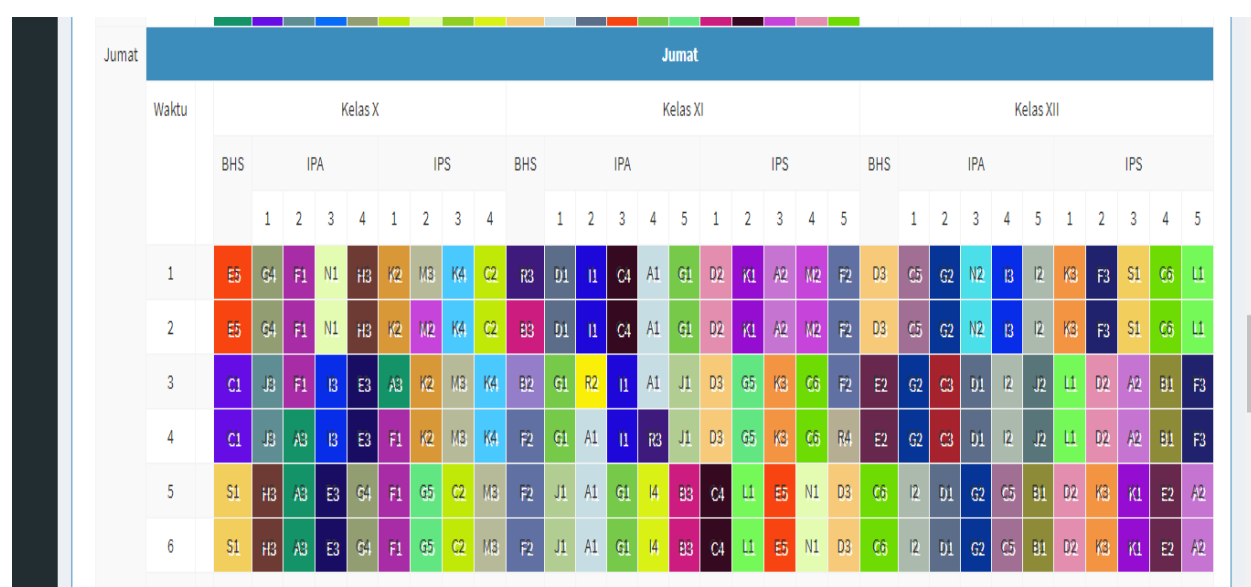

Gambar 20. Hasil Pengujian Jadwal E (Hari Jumat)

Tabel 6 adalah rangkuman hasil pengujian sebanyak 30 kali pengujian.

Tabel 6. Hasil pengujian aplikasi

\begin{tabular}{|c|c|c|c|c|c|}
\hline Pengujian Ke & Deskripsi & Pengujian ke & Deskripsi & Pengujian ke & Deskripsi \\
\hline 1 & $\begin{array}{l}\text { Tidak ada } \\
\text { yang } \\
\text { bertabrakan }\end{array}$ & 11 & $\begin{array}{l}\text { Tidak ada } \\
\text { yang } \\
\text { bertabrakan }\end{array}$ & 21 & $\begin{array}{l}\text { Tidak ada } \\
\text { yang } \\
\text { bertabrakan }\end{array}$ \\
\hline 2 & $\begin{array}{l}\text { Tidak ada } \\
\text { yang } \\
\text { bertabrakan }\end{array}$ & 12 & $\begin{array}{l}\text { Tidak ada } \\
\text { yang } \\
\text { bertabrakan }\end{array}$ & 22 & $\begin{array}{l}\text { Tidak ada } \\
\text { yang } \\
\text { bertabrakan }\end{array}$ \\
\hline 3 & $\begin{array}{l}\text { Tidak ada } \\
\text { yang } \\
\text { bertabrakan }\end{array}$ & 13 & $\begin{array}{l}\text { Tidak ada } \\
\text { yang } \\
\text { bertabrakan }\end{array}$ & 23 & $\begin{array}{l}\text { Tidak ada } \\
\text { yang } \\
\text { bertabrakan }\end{array}$ \\
\hline 4 & $\begin{array}{l}\text { Tidak ada } \\
\text { yang } \\
\text { bertabrakan }\end{array}$ & 14 & $\begin{array}{l}\text { Tidak ada } \\
\text { yang } \\
\text { bertabrakan }\end{array}$ & 24 & $\begin{array}{l}\text { Tidak ada } \\
\text { yang } \\
\text { bertabrakan }\end{array}$ \\
\hline 5 & $\begin{array}{l}\text { Tidak ada } \\
\text { Yang } \\
\text { bertabrakan }\end{array}$ & 15 & $\begin{array}{l}\text { Tidak ada } \\
\text { yang } \\
\text { bertabrakan }\end{array}$ & 25 & $\begin{array}{l}\text { Tidak ada } \\
\text { yang } \\
\text { bertabrakan }\end{array}$ \\
\hline 6 & $\begin{array}{l}\text { Tidak ada } \\
\text { yang } \\
\text { bertabrakan }\end{array}$ & 16 & $\begin{array}{l}\text { Tidak ada } \\
\text { yang } \\
\text { bertabrakan }\end{array}$ & 26 & $\begin{array}{l}\text { Tidak ada } \\
\text { yang } \\
\text { bertabrakan }\end{array}$ \\
\hline 7 & $\begin{array}{l}\text { Tidak ada } \\
\text { yang } \\
\text { bertabrakan }\end{array}$ & 17 & $\begin{array}{l}\text { Tidak ada } \\
\text { yang } \\
\text { bertabrakan }\end{array}$ & 27 & $\begin{array}{l}\text { Tidak ada } \\
\text { yang } \\
\text { bertabrakan }\end{array}$ \\
\hline 8 & $\begin{array}{l}\text { Tidak ada } \\
\text { yang } \\
\text { bertabrakan }\end{array}$ & 18 & $\begin{array}{l}\text { Tidak ada } \\
\text { yang } \\
\text { bertabrakan }\end{array}$ & 28 & $\begin{array}{l}\text { Tidak ada } \\
\text { yang } \\
\text { bertabrakan }\end{array}$ \\
\hline 9 & $\begin{array}{l}\text { Tidak ada } \\
\text { yang } \\
\text { bertabrakan }\end{array}$ & 19 & $\begin{array}{l}\text { Tidak ada } \\
\text { yang } \\
\text { bertabrakan }\end{array}$ & 29 & $\begin{array}{l}\text { Tidak ada } \\
\text { yang } \\
\text { bertabrakan }\end{array}$ \\
\hline 10 & $\begin{array}{l}\text { Tidak ada } \\
\text { yang } \\
\text { bertabrakan }\end{array}$ & 20 & $\begin{array}{l}\text { Tidak ada } \\
\text { yang } \\
\text { bertabrakan }\end{array}$ & 30 & $\begin{array}{l}\text { Tidak ada } \\
\text { yang } \\
\text { bertabrakan }\end{array}$ \\
\hline
\end{tabular}

\section{KESIMPULAN}

Berdasarkan hasil Penelitian ini, aplikasi Penjadwalan Mata Pelajaran Di SMAN31 berbasis Web menggunakan Algoritma Genetika, dapat disimpulkan bahwa Aplikasi ini dapat memberikan Hasil berupa Informasi Jadwal Mata Pelajaran di SMAN 31 beserta informasi mengenai nama Guru, Kelas, Jurusan, dan Grade. Algoritma Genetika yang berhasil diimplementasikan pada sistem dapat dibuktikan berdasarkan hasil Informasi Jadwal mata pelajaran yang merupakan hasil pengujian nya tidak memiliki bentrok antara 
jadwal 1 dan jadwal lainya, dengan mengimplementasikan algoritma Genetika proses penjadwalan mata pelajaran di SMAN31 menjadi lebih cepat dari proses manual.

\section{DAFTAR PUSTAKA}

[1] A. Nora, et al. 2012. "Penjadwalan Pesanan Menggunakan Algoritma Genetika Untuk Tipe Produksi Hybrid And Flexible Flowshop Pada Industri Kemasan Karton". Jurnal Teknik Industri ISSN: 1411 6380, pp. 176-188.

[2] W. A. Puspaningrum, 2013. "Penjadwalan Mata Kuliah Menggunakan Algoritma Genetika di Jurusan Sistem Informasi," ISSN: 2337-3539, vol. II, pp. 127-131.

[3] R. Destia, 2013. "Perancangan Aplikasi Prnjadwalan Mata Pelajaran Menggunakan Algoritma Genetika," Pelita Informatika Budi Darma, ISSN: 2301-9425, vol. V, pp. 148-151.

[4] Krisnandi, K. and Agung, H. 2017. "Implementasi Algoritma Genetika untuk Memprediksi Waktu dan Biaya Pengerjaan Proyek Konstruksi”. Jurnal FIFO.

[5] Widodo, A. W. and W. F. Mahmudy. 2010, "Penerapan Algoritma Genetika Pada Sistem Rekomendasi Wisata Kuliner", Jurnal Ilmiah KURSOR, Vol.5. No.4.

[6] Goldberg, D. 1987. "Computer-aided gas pipeline operation using genetic algorithm and rule learning”. e-ISSN: 1435-5663, e-ISSN 0177-0667. 